\title{
CREATIVE PERFORMANCE MEASUREMENT IN DESIGN EDUCATION: PRODUCT DIMENSION*
}

\author{
TASARIM EĞITIMINDE YARATICI PERFORMANSI ÖLÇME: ÜRÜN BOYUTU
}

\author{
Esra Varol**
}

\begin{abstract}
One of the important dimensions of measurement and evaluation in design education is the product. According to various criteria, the products designed by the students are measured by the faculty using the jury approach, the traditional performance measurement and evaluation method in design education, and the student success is decided upon. The most important criterion in measuring and evaluating of student success in design education is the product's creativity. The purpose of this study is to identify the criteria the Fashion Design and Industrial Design faculty uses in a product's performance measurement during the programs' last year studio courses and to discuss the criteria and definitions in both of these design fields and to examine the process followed to decide upon a student's success. Qualitative research was employed in the study. Creativity was found to be the main criterion in the performance measurement of a product in both design fields.
\end{abstract}

Keywords: Design education, Performance measurement, Product dimension, Fashion design, Industrial design.

Öz

Tasarım eğitiminde öğrencinin başarısını ölçme ve değerlendirmede önemli boyutlardan bir tanesi üründür. Öğrencilerin tasarladıkları ürünler, çeşitli ölçütlere göre tasarım eğitiminin geleneksel performans ölçme ve değerlendirme yöntemi olan jürili yaklaşım ile öğretim elemanları tarafından ölçülmekte ve öğrencinin başarısına karar verilmektedir. Tasarım eğitiminde öğrenci başarısını ölçme ve değerlendirmede en önemli ölçüt ürünün yaratıcılı̆ıııı. Bu araştırmanın amacı, Moda Tasarımı ve Endüstriyel Tasarım programlarında yer alan son sınıf stüdyo derslerinde ürüne yönelik performans ölçmede öğretim elemanlarının kullandığı ölçütleri belirlemek, her iki tasarım alanında kullanılan ölçütleri ve tanımlarını tartışmak ve öğrenci başarısına karar verme sürecini incelemektir. Araştırmanın yöntemi niteldir. Araştırma sonuçlarından bir tanesi her iki tasarım alanında ürüne yönelik performans ölçmede kullanılan başlıca ölçütün yaratıcılık olmasıdır.

Anahtar Kelimeler: Tasarım eğitimi, Performans ölçme, Ürün boyutu, Moda tasarımı, Endüstriyel tasarım.

Başvuru tarihi: 03.03.2018 - Kabul tarihi: 04.07.2018

* 26-28.05.2016 tarihleri arasında gerçekleştirilen 5th World Conference on Design and Arts (WCDA-2016)'da Türkçe olarak sunulmuş, ancak tam metin olarak yayınlanmamıştır.

** Dr. Öğr. Üyesi, Anadolu Üniversitesi, Mimarlık ve Tasarım Fakültesi / Moda ve Tekstil Tasarımı Bölümü /

Moda Tasarımı Anabilim Dalı, Eskişehir, evarol@anadolu.edu.tr. 


\section{SDÜ ART-E}

Güzel Sanatlar Fakültesi Sanat Dergisi

\section{Introduction}

In the literature, the term design refers to the words like design task, to conceive projectdrawing-process, original-creative product-model and visual composition. In accordance with these meanings, design is process and product. As a process, it means planning, organizing, putting effort to be successful, achieving a special purpose and creating something while reaching a goal. As a product, it means an end, result, output of a plan or process and deliberate organization. As a process and product, a design includes everything that has been deliberately created by people (Davis, 1987:1).

Design is classified in various ways in science, education and business life, in terms of subject of the case, science that is worked on and product to put forward. This classification can be done according to the fields like fashion design, industrial products design, graphic design, interior design, packaging design and also it can be done according to the dimension of the product like two, three or four dimensional (Mozota Borja De, 2006:21) (Table 1.)

Table 1. Design fields according to product dimensions

\begin{tabular}{|l|l|l|}
\hline \multicolumn{1}{|c|}{ 2D Design } & \multicolumn{1}{|c|}{ 3D Design } & \multicolumn{1}{c|}{ 4D Design } \\
\hline - Graphic Design & - Fashion Design & - Digital Design \\
- İnformation Design & - Furniture Design & - Web Design \\
- Textile Design etc. & - Interior Design & - Interactive Design etc.. \\
& - Industrial Design etc. & \\
\hline
\end{tabular}

Designer is an innovative and trend developer individual who creates a change, tries to be imaginative and produces an idea (Mozota Borja De, 2006:17). In the design field, higher education institutions aim to train creative designers with their undergraduate programs. Determining whether the existing applications in undergraduate education in design are effective to reaching goals and realizing desired changes for students' behaviors necessitates effective measurement and evaluation. Determining the extent if they are effective, addressing problems if there are any and motivating and sustaining success, also, necessitate effective measurement and evaluation. 
It is not possible to determine the success of a student by traditional approaches called paper and pencil tests or by designs produced in two or three dimensional creative products based on complex skills. This situation makes the evalution of design education be a subject of performance evaluation which is called as "alternative measurement method" in evaluation of compex skills (Nitko, 2004:236).

Performance-based assesments in education are for evaluation of complex skills. Evaluating the performance which is an important fundamental of determining the qualities of a learning process, the way followed during process and a product produced after a performance, requires students to show their knowledge and skills. In other words, the subject of performance measurement is not solely about knowing but also about doing (Linn \& Miller, 2005:250-261). In design education, the courses in which design performance is heavily based on knowledge and performance can be considered as the studio courses.

Studio courses which the students use all the knowledge and skills they have learned about design in solving design problems are the main courses of the design programs. They are presented in different grades. In these courses, especially in the senior year studio courses, students are expected to be at their highest creative performance level in order to solve design problems. The final exams (exams at the end of the semester) of these courses are the courses when the design process is completed and performances of students' designs are evaluated as a whole. In these exams, products are one of the most important dimensions of the evaluation of design performance.

In performance measurement of two or three dimensional designs, the most important subject is to determine performance criteria. Criteria of deciding student performance are the basis of a valid and a reliable evaluation. In scientific studies related to design education, even though the subject of measurement and evaluation with its dimensions like performance criteria and measurement tools has been studied more recently, it is still one of the subjects studied the least.

Particularly in design fields, studies on measurement and evaluation of creative performance with its product, process and personal dimensions are limited. In terms of 


\section{SDÜ ART-E}

Güzel Sanatlar Fakültesi Sanat Dergisi

measuring creativity, while some studies discuss how product and process should be discussed together, some studies discuss dimensions of creativity such as product, process, human or environment (Hennessy 1994:193-208; Casakin 2007:21-33; Hasirci and Demirkan, 2003, 17-41; Hasirci and Demirkan 2007:259-271; Demirkan and Hasirci, 2009:294-301; Harpe et al. 2009:3751). In addition, some studies focus on product creativity with its various aspects (Besemer, 1998: 333-346; Besemer and O'Quin, 1999:287-296; Kidd and Workman, 1999:58-64; Christiaans, 2002:41-54; Horng and Lin, 2009, 54-63; Varol, 2010).

Design education is based on creativity which is one of the most difficult concepts to understand. Design problems may have infinite correct solutions as it may have ideas, drawings and products. To reach these solutions, multidimensional skills should be used together. Due to this situation, the scientific studies done in this field and scientific studies done in measurement and evaluation are difficult. Despite this difficulty, studies on measurement and evaluation will contribute to design in general and also contribute to the field of design with its various aspects and to the education provided in this field.

Accordingly, the purpose of this study is to determine the criteria that the instructors use in performance measurement of products in senior year studio courses offered in Fashion Design and Industrial Design programs, to discuss the criteria and definitions used in both fields and examination of the process of deciding student success.

\section{Method}

This study's method is related with the problem, the approach followed while solving the problem and the analysis method. The study sample is made up of five instructors working in the Department of Fashion Design and Industrial Design of Anadolu University's Faculty of Architecture and Design. While three of these instructors work in the Department of Industrial Design, two of them work in Department of Fashion Design. To determine the study sample, "Criterion Sampling Method", one of the purposive sampling methods, was used. This method involves studying all the cases meeting some predetermined criteria. These criterions or criteria can be developed by the researcher or a pre-prepared criteria list (Yıldırım \& Şimşek, 2008:112). 
According to Criterion sampling Method, the criteria developed and used by the researcher to determine the study sample are as follows:

- Instructors have to have at least 10 years of experience,

- Instructors had to give the senior year studio courses which are called Fashion Show Project and Product Design VI in fashion and industrial design programs at least once and evaluate the performance in the final exam,

- To be volunteered in being part of the sample group to collect study data.

The study was conducted in the spring semester of 2015-2016 academic year. Form's of the evaluation of courses which studied in this research are two midterm and one final for two departments. Fourteen weeks of courses are taught during one semester and a number of students are approximately 65 for each department. To obtain the data, interviews between 8 minutes 41 seconds and 40 minutes and 43 seconds were done with the instructors. In a structured interview, what kind of questions, how the questions will be asked and what kind of data will be reached are planned and in an unstructured interview, even though the interview questions are known in advance, new questions about various aspects of the subject can be asked during the interview. The semi-structured interview is an interview type between these aforementioned interview types (Karasar, 2005:167-168). In this study, a semi-structured interview was preferred. The voice recordings (through an audio recorder) of the instructors participating in the study were turned into a written format of 30 pages long document. The study findings were reached through the descriptive analysis of the interview data. According to this approach, the data obtained are summarized and interpreted according to predetermined themes. While the data can be organized based on the themes that is put forward by the study questions, they can also be presented by taking the questions or dimensions used during the interview and observation process into account (Yıldırım \& Şimşek, 2006:224).

\section{Findings}

Findings obtained as a result of descriptive analysis of the data, which are collected through interviews that are presented in the same order, as the questions are being asked during the interview. 
SDÜ ART-E

Güzel Sanatlar Fakültesi Sanat Dergisi

Haziran'18 Cilt:11 Sayı:21

ISSN 1308-2698

\subsection{The Approaches to Measurement Of Student Performance in The Final Exam Of} The Senior Year Studio (Project) Courses:

All of the instructors in the sample stated that their measurement approach in the final exam of the senior year studio courses is the jury approach. Common jury members of both the Fashion Design Department and Industrial Design Department are the instructors teaching the senior year project courses. While instructors from various universities take part in Fashion Design Department juries, representatives from firms which the students worked together in line with the content of their project courses and guests from various sectors take part in Industrial Design Department juries. The number of jury members for both of the departments is between 8 and 15. The examples from the answers given by the instructors to the study's first question are as follows:

Fashion Design Interview 1: "We use the jury approach... all of the teachers who teach senior courses, actually all of the teachers who teach project courses form the jury. This year other teachers from various universities participated, too".

Industrial Design Interview 1: "We only do jury measurement in the final exam. The jury members, are first of all, comprised of the course teachers. Then, design managers of the firms the students work with and guests from the invited sectors can make up the jury. The jury is made up of at least 10-15 people and it is a crowded jury".

\subsection{The Student Products That Are The Performance Subjects in The Final Exam Of}

\section{The Senior Year Studio Courses:}

Performance products for both fashion design and industrial design fields are essentially divided into two as two-dimensional and three-dimensional products. In fashion design, the two-dimensional products used in the measurement of student performance in final exam of the senior year studio courses are storyboards, artistic and technical drawing sheets, fashion photographs and process files. The three-dimensional products are prototypes or real designs. In industrial design, the two-dimensional products used in the measurement of student performance in final exam of the senior year studio courses are technical drawings and product drawing sheets and videos. Three-dimensional products like models, prototypes or real products 
made for the student project are what is different for the industrial design field. The explanations of the participating instructors regarding the subject as follows:

Fashion Design Interview 1: "They come with both two-dimensional and three-dimensional products. Two-dimensional products are sheets, storyboards and this time they have a file with their fashion photographs. They come with their files, with their process files. These are our two-dimensional products. They bring the three-dimensional products in the form of five products. They put these on the models they have choosen before. They can be women or men. We evaluate according to that".

Industrial Design Interview 3: "The scale for industrial products design may vary a lot. Well, some students make a glass bottle, glass set and some students make electric car or even a truck for graduation projects. So, presentation materials change according to the product's scale. Sheets that have cross-sections, technical drawings, the relation between the product and the user, the look of the usage scenarios, the details and the materials are definitely required... we later ask them to present a video including information about their research process, design process and the product if needed".

\subsection{Usage Of Measurement Tool/Tools And The Qualities Of The Measurement} Tool/Tools Which Used In Measurement Of Student Performance in The Final Exam Of The Senior Year Studio Courses:

While participating, Fashion Design Department instructors expressed that they use a performance measurement tool, Industrial Design department instructors stated that they are working on this but they do not have a measurement tool yet. The measurement tool used in the final exam of the senior year studio courses in Fashion Design Department is a scorecard made up of criteria like $R \& D$ (10 points), production quality ( 25 points), appropriateness to the theme (15 points), originality of the design (30 points) and design aesthetics (20 points). The examples from participating instructors' answers regarding the subject as follows:

Fashion Design Interview 2: "Yes, we use. We have an evaluation criteria. We have an evaluation criteria including student's product design, product process, aesthetics based on technical characteristics and originality".

Industrial Design Interview 2: "We started to work on this three years ago, we said let's work. Each teacher has their own individual scoring system (inside the jury). Everybody respected each other's scoring system".

Industrial Design Interview 3: There is no common written evaluation criteria among the jury members but each jury member has a criterion that he/she puts forward, that he gives importance to and that he finds essential or each jury member has their own criteria ranking 
and jury members evaluate student work based on these criteria according to their perspectives".

\subsection{Criteria Which Were Used in The Measurement Of Products in The Final Exam Of} The Senior Year Studio Courses:

\subsubsection{Criteria for two-dimensional products:}

The criteria for two-dimensional products in fashion design reached through descriptive analysis of the data obtained from the participating Fashion Design Department instructors are as follows:

\section{Storyboard}

$\checkmark \quad$ Creating a composition explaining the design idea using visual examples and information texts

Technical drawings

$\checkmark \quad$ Using the drawing paper appropriate to the composition principles

$\checkmark \quad$ Drawing the clothing's model characteristics appropriate to the technical drawing principles (gathering, cup, dart, etc.)

$\checkmark \quad$ Drawing the clothing's production characteristics (stitching, size) appropriate to technical drawing principles

Artistic drawings

$\checkmark \quad$ Using the drawing paper appropriate to composition principles

$\checkmark \quad$ Drawing an original fashion figure

$\checkmark \quad$ Drawing the fashion figure proportional and aesthetic in terms of body

$\checkmark \quad$ Coloring appropriate to the technique showing the design details (texture, color, etc.)

\section{Process file}

$\checkmark \quad$ The power to summarize the design process and what the student did during this process 
The criteria for two-dimensional products in industrial design reached through descriptive analysis of the data obtained from the participating Industrial Design Department instructors are as follows:

\section{Technical drawings}

$\checkmark \quad$ Using the drawing paper appropriate to the composition principles

$\checkmark \quad$ Drawing appropriate to technical drawing rules and characteristics like scale, line thickness and scaling

$\checkmark \quad$ Drawing production details correctly

\section{Product drawings}

$\checkmark \quad$ Using the drawing paper appropriate to composition principles

$\checkmark \quad$ Drawing in a way to show the product-user relationship

$\checkmark \quad$ Drawing in a way to show the design purpose and usage scenarios

$\checkmark \quad$ Realistically and impressively drawing the product in detail and with its characteristics like color and material

Video

$\checkmark \quad$ Visually narrating the research, design process and product

The explanations of the participating instructors regarding the subject as follows:

Fashion Design Interview 2: "...an important criterion for me is the sheet organization, I mean, is it appropriately placed on the sheet in terms of composition? The originality of the fashion figure, did the student draw using her own figure? Does the fabric used or materials used feel correct? If it is velvet, the drawing should be for the velvet, if it is silk, the drawing should be for the silk. Technical drawings should be on this sheet, too. Can these be understood when looked at? Are technical characteristics like gathering, cup and others on it?"

Industrial Design Interview 2: "Technical drawing is of course very regular. The line thickness is known, the scales are known... There are not many questions. We want the essential in the final. This is in a way the guarantee of the product's manufacturability, in other words if you can do the technical drawing of something, you can produce it. Of course the impressiveness of the sheet, impressiveness of the graphic work is the most important part of the job. Everything, composition, color, the density of the writing and visual, these are all the things we talked about in basic design. This is what we call beautiful or ugly when we see it". 


\section{SDÜ ART-E}

Güzel Sanatlar Fakültesi Sanat Dergisi

Haziran'18 Cilt:11 Sayı:21

ISSN 1308-2698

\subsubsection{Criteria for three-dimensional products:}

Participating Fashion Design Department instructors listed the performance criteria for three-dimensional products as appropriateness to the target audience, appropriateness to the theme, creativity, novelty, originality, production quality, functionality, consistency between 2D and 3D designs, appropriateness to industrial manufacturing and aesthetics (Figure 1.). While talking about the creativity criteria, they talked about the product being new, surprising and having different characteristics and also having the power of belonging to the designer. Appropriateness to the target audience was defined as being appropriate to target people's characteristics like age, social status and lifestyle. Functionality refers to whether people wear the product or not. Appropriateness to industrial manufacturing was a criterion stated as changeable depending on the collection type. Aesthetics criterion was explained with design principles. Example dialogues about the subject are as follows:

Fashion Design Interview 1: "Well, we evaluate their products to see if they are aesthetic. Creativity for me is being surprising. Appropriateness to the theme is actually a criterion".

Fashion Design Interview 2: "Creativity is important in clothing design. Because if we are giving design education, it needs to be different. Foremost, it shouldn't be an ordinary clothing design. We want distinctiveness even in a plain t-shirt or a basic combed cotton t-shirt. Originality is actually uniqueness, being the only one, in other words being different than the others. We want the students to have their own signature in terms of design... target audience is important. When we think about real life, I mean when we think about commercially, the target audience definitely needs to be determined. I can say this about being appropriate to industrial manufacturing, in fourth year it needs to be functional. Of course when it goes through process analysis, it needs to be for ready-made industry... Of course one of the most important items is its functionality. Is it a functional dress? Is there a problem while putting it on and taking it off?" 
SDÜ ART-E

Güzel Sanatlar Fakültesi Sanat Dergisi

Haziran'18 Cilt:11 Sayı:21

ISSN 1308-2698

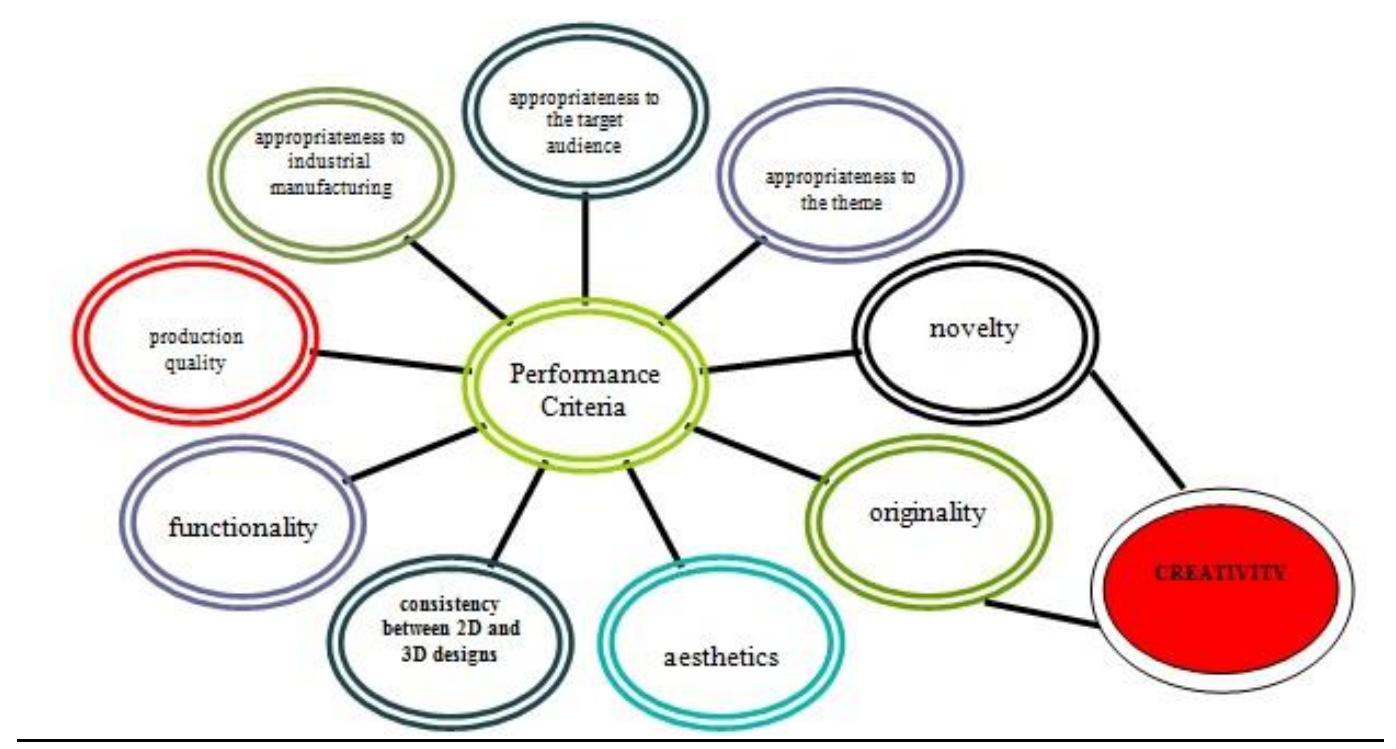

Figure 1. Performance criteria for three-dimensional products in fashion design.

Participating Industrial Design Department instructors listed the performance criteria for three-dimensional products as appropriateness to the target audience, creativity, novelty, originality, production quality, consistency between 2D and 3D designs, functionality, ergonomics and aesthetics (Figure 2.).

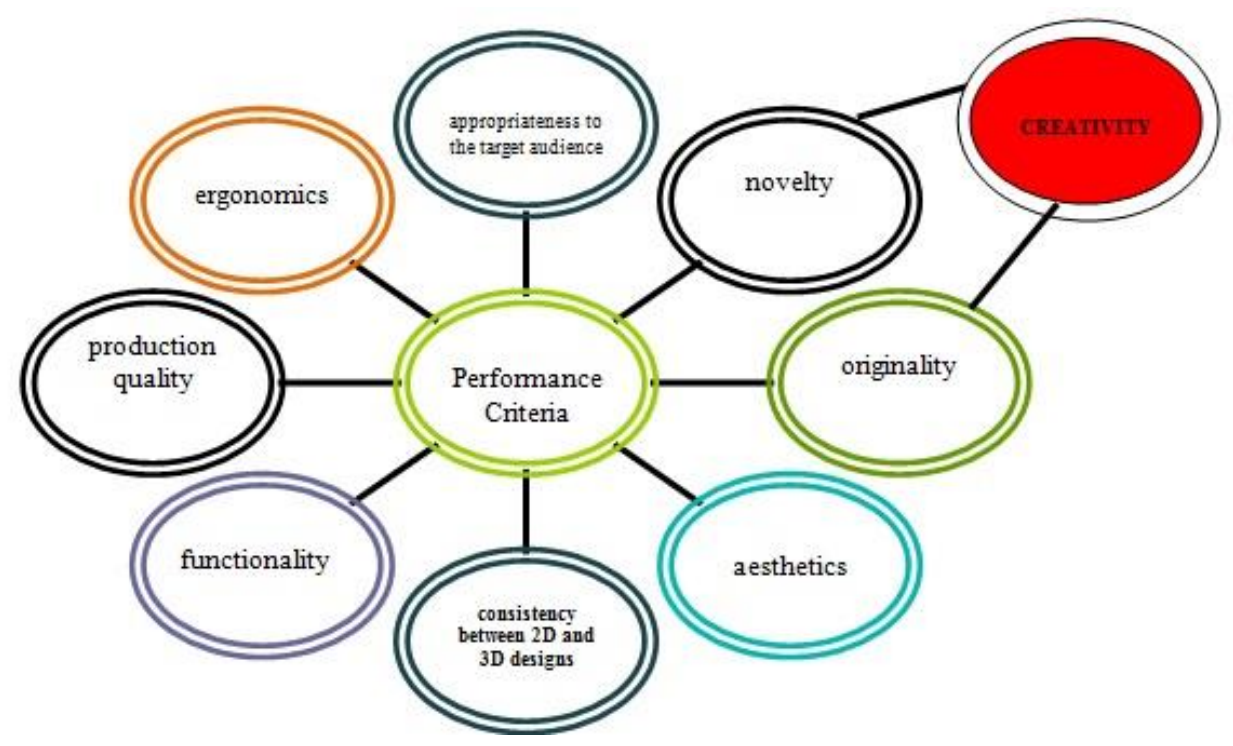

Figure 2. Performance criteria for three-dimensional products in industrial design. 
SDÜ ART-E

Güzel Sanatlar Fakültesi Sanat Dergisi

Haziran'18 Cilt:11 Sayı:21

ISSN 1308-2698

Creativity criterion was defined by the instructors as the product being different and original compared to others. Creativity criterion is also defined as the product that was not produced before. Production quality referred to the three-dimensional products (model or real) being correct in terms of characteristics like model workmanship, details, likeness of the materials used and aesthetics criterion referred to the design principles and using these accurately. Functionality criterion was explained as the power of the product fulfilling its usage purpose in different scenarios and ergonomics criterion was explained as the product being physically appropriate to the user and being safe to use.

Industrial Design Interview 1: "I mean we give importance to the consistency between twodimensional and three-dimensional products. We expect both to indicate the same product. If I need to give an example, it can be color... we care about model workmanship here. Of course in a graduation project, model workmanship has to come to a good point, to a good level. I mean, whatever the material she is using, she needs to cut it good, she needs to work on it good and she needs to sand the surface good. It is important to relate creativity with novelty. We need to look at factors forming novelty. One of them is having a distinctiveness in the product's function. Being distinct only in the function is not enough. For example, a vacuum cleaner can perform with a different hand grip. But it also needs to reflect on the form".

Industrial Design Interview 2: "Because creativity and originality is in the definition of design, I mean because they are expected to make something new and original, this is a basic criterion, I mean it shouldn't look like other products, we expect the product to be different than the products in the market... Originality in its simplest definition is the product was not made before... If there aren't extreme similarities, we consider them original... I mean to make the user's job easier, recently there is a trend in industrial design, user-based design... Aesthetics is very subjective... It is last thing we talk about, ratio-proportion, color theory, complementary contrast colors, these are all of course being talked. We talk about from rhythm to ratio, everything... Functionality is a must but a product needs to fulfill its purpose, I mean an orange squeezer that cannot squeeze orange is not actually a product".

\section{Conclusions and Interpretations}

Studio courses where the students use all the knowledge and skills they have learned about design in solving design problems are the main courses of the design programs. It is not possible to measure student success by traditional measurement approaches called paper and pencil tests and by designs produced as creative products. Measurement in the design field is the subject of performance measurement.

With the purposes of determining the criteria the instructors use in performance measurement of products in senior year studio courses offered in Fashion Design and Industrial 


\section{SDÜ ART-E}

Güzel Sanatlar Fakültesi Sanat Dergisi

Design programs, discussing the criteria and definitions used in both fields and examining the process of deciding student success this study is conducted and the results are as follows:

For both Fashion Design and Industrial Design departments, the adapted measurement approach in the final exams of the senior year studio courses is the jury approach, the traditional measurement approach of design education. For both of the departments, the common jury members are the instructors teaching the senior year project courses.

While participators of Fashion design Department instructors use a performance measurement tool, Industrial design Department instructors do not use any measurement tool. The measurement tool used in the final exam of the senior year studio courses in Fashion Design Department is a scorecard made up of criteria like R \& D (10 points), production quality (25 points), appropriateness to the theme (15 points), originality of the design (30 points) and design aesthetics (20 points). Usage of measurement tools is really important to reliability of performance measurement. Also, student diserves to know method of measurement.

Performance products for both fashion design and industrial design fields are essentially divided into two as two-dimensional and three-dimensional products. In fashion design, the twodimensional products used in the measurement of student performance in final exam of the senior year studio courses are storyboards, artistic and technical drawing sheets, fashion photographs and process files. The three-dimensional products are prototypes or real designs. In industrial design, the two-dimensional products used in the measurement of student performance in final exam of the senior year studio courses are technical drawings and product drawing sheets and videos. Three-dimensional products like models, prototypes or real products made for the student project are what is different for the industrial design field.

The criteria for two-dimensional products in fashion design reached through descriptive analysis of the data obtained from the participating Fashion Design Department instructors are as follows:

\section{Storyboard}

$\checkmark \quad$ Creating a composition explaining the design idea using visual examples and information texts 


\section{SDÜ ART-E}

Güzel Sanatlar Fakültesi Sanat Dergisi

\section{Technical Drawings}

$\checkmark \quad$ Using the drawing paper appropriate to the composition principles

$\checkmark \quad$ Drawing the clothing's model characteristics appropriate to the technical drawing principles (gathering, cup, dart, etc.)

$\checkmark \quad$ Drawing the clothing's production characteristics (stitching, size) appropriate to technical drawing principles

Artistic Drawings

$\checkmark \quad$ Using the drawing paper appropriate to composition principles

$\checkmark \quad$ Drawing an original fashion figure

$\checkmark \quad$ Drawing the fashion figure proportional and aesthetic in terms of body

$\checkmark \quad$ Coloring appropriate to the technique showing the design details (texture, color, etc.)

Process File

$\checkmark \quad$ The ability to summarize the design process and what the student did during this process

The criteria for two-dimensional products in industrial design reached through descriptive analysis of the data obtained from the participating Industrial Design Department instructors are as follows:

Technical Drawings

$\checkmark \quad$ Using the drawing paper appropriate to the composition principles

$\checkmark \quad$ Drawing appropriate to technical drawing rules and characteristics like scale, line thickness and scaling

$\checkmark \quad$ Drawing production details correctly

\section{Product Drawings}

$\checkmark \quad$ Using the drawing paper appropriate to composition principles

$\checkmark \quad$ Drawing in a way to show the product-user relationship

$\checkmark \quad$ Drawing in a way to show the design purpose and usage scenarios 
SDÜ ART-E

Güzel Sanatlar Fakültesi Sanat Dergisi

Haziran'18 Cilt:11 Sayı:21

ISSN 1308-2698

$\checkmark \quad$ Realistically and impressively drawing the product in detail and with its characteristics like color and material

$\underline{\text { Video }}$

$\checkmark \quad$ Visually narrating the research, design process and product

For the fashion design, performance criteria for three-dimensional products are appropriateness to the target audience, appropriateness to the theme, creativity, novelty, originality, production quality, functionality, consistency between 2D and 3D designs, appropriateness to industrial manufacturing and aesthetics. For industrial design, performance criteria for three-dimensional products are appropriateness to the target audience, creativity, novelty, originality, production quality, consistency between 2D and 3D designs, functionality, ergonomics and aesthetics.

When all the results are taken into consideration, creativity, originality, novelty, aesthetics, functionality and consistency between two- and three-dimensional products are common criteria in the measurement of three-dimensional products in the senior year final exams of both Fashion Design and Industrial Design departments. However, there are differences in between some of the criteria. For example, while the fashion design instructors define originality criterion as the product's power of belonging to the designer in being different than others, the industrial design instructors define this criterion as the product's power of being different than the others. Also, while ergonomics is a separate criterion for the industrial design product, it is a criterion that is sought after inside the production quality criterion in fashion design. Apart from these, criterion of creative performence are similar to the other researches which were worked in similar subject related to the fashion design and the industrial design.

\section{References}

Besemer, S. P. (1998). "Creative product analysis matrix: testing the model structure and a comparasion among products-three novel chairs", Creativity Research Journal, Vol 11, No 4, p. 333-346.

Besemer, S. P. and O'Quin, K. (1999). "Confirming the three-factor creative product analysis matrix model in an american sample", Creativity Research Journal, Vol 12, No 4, p. 287-296. 
SDÜ ART-E

Güzel Sanatlar Fakültesi Sanat Dergisi

Haziran'18 Cilt:11 Sayı:21

ISSN 1308-2698

Casakin, H.P. (2007). "Methaphors in design problem solving: implications for creativity", International Journal of Design, Vol 1, No 2, p. 21-33.

Christiaans, H.H.C.M. (2002). "Creativity as a design criterion", Creativity Research Journal, Vol 14, No 1, pp. 41-54.

Davis, M.L. (1987). Visual Design in Dress (Second Edition), USA-New Jersey: Prentice- Hall Inc.

Demirkan, H. and Hasirci, D. (2009). Hidden dimensions of creativity elements in design process, Creativity Research Journal, Vol 21, No 2-3, p. 294-301.

Harpe, de la B., Peterson, J.F., Frankham, N, Zehner, R., Neale D., Musgrave, E. and McDermott, R. (2009). "Assessment focus in studio: what is most prominent in architecture, art and design?", International Journal of Art and Design Education, Vol 28, No 1, p. 37-51.

Hasirci D. and Demirkan H. (2003). "Creativity in learning environments: the case of two sixth grade art-rooms". The Journal of Creative Behavior, Vol 37, No 1, p. 17-41.

Hasirci D. and Demirkan H. (2007). "Understanding the effects of cognition in creative decisionmaking: a creativity model for enhancing the design studio process", Creativity Research Journal, Vol 19, No 2, p. 259-271.

Hennessey, B. A. (1994). "The conselsual assessment technique: an examination of the relationship between ratings of product and process creativity", Creativity Research Journal, p. 193-208.

Horng J-S. and Lin, L. (2009). "The development of a scale for evaluating creative culinary products", Creativity Research Journal, Vol 21, No 1, p. 54-63.

Karasar, N. (2005). Bilimsel Araştırma Yöntemi. Ankara: Nobel Yayn Dağıtım.

Kidd, L.K. and Workman, J.E. (1999). "Assessment of creativity in apparel design", Clothing and Textiles Research Journal, Vol 17, No 1, p. 58-64.

Linn, L.R. and Miller, M.D. (2005). Measurement and Assessment in Teaching. (9th Edition). New Jersey -USA: Pearson Education Inc.

Mozota Borja De, B. (2006). Tasarım Yönetimi, çev. Sibel Kaçamak, İstanbul: MediaCat Kitapları.

Nitko, A.J. (2004). Educational Assessment of Students. (4th ed.). USA-New Jersey: Pearson Education Inc.

Varol, E. (2010). Moda Tasarımı Egitiminde Tasarımların Degerlendirilmesine Yönelik Bir Ölçme Aracı Geliştirme, Doktora Tezi, Gazi Üniversitesi, Eğitim Bilimleri Enstitüsü, Giyim Endüstrisi ve Moda Tasarımı Eğitimi Anabilim Dalı, Ankara, Türkiye.

Yıldırım, A. ve Şimşek, H. (2008). Sosyal Bilimlerde Nitel Araştırma Yöntemleri. (6.Baskı). Ankara: Seçkin Yayıncılık. 